\title{
The Lord of the Flaws
}

\author{
The Autonomy of the Artist and the Function of Art
}

\author{
Reinold Schmücker
}

\begin{abstract}
In aesthetics a misleading idea of autonomy prevails: art is autonomous because it does not serve any heteronomous purposes. This conviction is deeply rooted in the philosophy of art from Romanticism to Heidegger and Adorno. However, it is not convincing because art is functional in various ways. It can have a variety of very different purposes - including some that the artist does not approve. Against this background, the article focuses on a peculiarity of modern aesthetics which has not been noticed so far: the development of the modern concept of art has made the category of the mistake almost disappear. Works of art are taken to be something given which is not supposed to be examined for mistakes but to be explained and made understandable by the artistic decisions they are based on. By reflecting this peculiarity, the author develops an understanding of the autonomy of art as a normative artistic competence, which is compatible with the functionality of works of art and can help to clarify the social importance of art.

KEYWORDS Modern concept of art, autonomy of art, artistic autonomy, functionality of art, aesthetic mistakes, function-related art criticism, conceptionrelated art criticism
\end{abstract}

Are artists capable of mistakes? For Plato and Aristotle the case was clear: In Plato's view everything artists might be capable of was imperfect in principle; for everything they might achieve at all was an imperfect reproduction of the true - that is: of the idea of a visible object. Aristotle, on the other hand, distinguishes two kinds of mistakes which might happen to artists: the imperfect copy which is due to the artist's inability to depict, as it is expressed by making a painting, for example, which does not show its subject anymore, and mistakes which are due to a lack of knowledge of the topic, for example if the artist does not know that a hind has no antlers. Although for Aristotle a lack of knowledge of the latter kind can rather be excused than inability to depict, in his opinion also this must be avoided: "For," he says in the 25th chapter of Poetics, "every kind of error should, if possible, be avoided."1 As long as the fine arts were technai, that is cultural techniques the rules of which could be taught and learned, this maxim was valid. Accordingly, still today even a generally highly appreciated artist such as Leonardo, whose work was created at the threshold of the modern Western concept of art, must accept the reproach that "both in the sense of perspective and in respect of anatomy" his Annunciation "shows certain flaws." 
In respect of a work of graphic art of today, such a notice of a defect would be strange. Who would dare judge a work according to standards which do not come from the work itself and which would be brought up as if they were a matter of course? In the case of Thomas Struth's Audience works, of a photography by Araki, a painting by Baselitz, or in the case of Beuys's Tram Station, what could that be which might be called a mistake as if criteria went without saying? Max Liebermann, to critics objecting that in their opinion the arm of Cézanne's Boy in a Red Vest was too long, answered "that such a beautifully painted arm could not be long enough at all."3 More academic, but just as clear is the art-historic defence of Cézanne by the art historian and exhibition organizer Götz Adriani:

The decision for this length, which rests heavily on the leather of the trousers whose spontaneous white could not have been done better by Frans Hals, was necessary to stabilize the posture which follows the curve of the back. However objectively, as if looked at through the lense of a camera, the seemingly distorted scale and the abrupt differences of size are correctly seen. ${ }^{4}$

Apologies such as this one show that today even aesthetics understands works of art to be something given which shall not be examined for mistakes but be explained and made understandable by the artistic decisions they are based on. Thus, are artists not at all capable of mistakes today?

Indeed, the development of the modern Western concept of art has made the category of mistakes almost disappear in the philosophy of art. In the indices of terms of Hegel's Ästhetik (Aesthetics) and Adorno's Ästhetische Theorie (Aesthetic Theory) the term Fehler (mistake) is completely missing, and similarly in the aesthetic encyclopedias of the past 200 years - I proved the German ones and most of the English written ones - there is no entry on the keyword mistake; neither in Hebenstreit's Encyklopödie der Aesthetik (Encyclopedia of Aesthetics) from the year 1843 nor in the only recently completed German historic dictionary Ästhetische Grundbegriffe (Basic Notions of Aesthetics) where right after the entry Exotisch/ Exotismus follows the lemma Fest/Feier. Also in other works there is a remarkable gap between fascination and feminist aesthetics. And the expression Kunstfehler (professional error), which the criminal law knows for a mistake of medical treatment as early as in the 19th century, has for the time being found its way into the world of art as the name of magazines and galleries but not with any aesthetic meaning. This forgetting about the mistake of modern aesthetics reflects a strange fact: today - and this means: under the condition of the modern Western concept of art - an artist is capable of mistakes only in quite a certain sense. 
Of course it is always possible that with artistic work something goes wrong. A brushstroke does not produce the desired result; the drill penetrates the stone more deeply than intended; the etching needle fails to produce the intended engraving. Every artist will have accused himself of having made such a mistake at least once. Then, often he tries to correct it. If, however, with hindsight this mistake is understood to have been a lucky coincidence, if it stays hidden or is not corrected for any other reason, if the work is exhibited without correction or left to a proprietor of a gallery to be sold, it is authorized exactly as it is. An observer may consider it a failure. The observer's accusation that the work has flaws, however, is made irrelevant if the artist - by word or deed - makes clear that he intended the work as it is. On the other hand, the artist himself may judge an earlier work as having flaws - as e.g. Jeff Wall did with his photography Eviction Struggle from the year 1988 when he worked it over digitally in the year 2004. For the concept of mistake names the violation of a norm or a standard. However, for any work of art the norm or standard according to which a mistake may be stated is - under the condition of the modern Western concept of art - defined by the artist himself. A physician may produce a professional error because the rules and standards he follows have developed as the result of a co-operative process and have solidified to inter-subjectively valid norms - the experiences of a number of physicians have contributed to these standards and they have been made generally valid by laws and regulations. In contrast to this, the artist is alone: also he knows a great number of experiences which have been made by other artists in different fields of the arts when working with their material - at least as far as these experiences can be read from their works or can be taken from statements by these artists but for him these experiences will always be other people's experiences, and it is his own decision if he draws conclusions from them or not.

Thus only if the artist agrees with the observer and admits a mistake, there may be talk of the work having flaws. In other words, it is the artist's privilege to make mistakes only he himself understands to be mistakes because it is his privilege to decide about his works being flawless or not. However, the field of architecture is a special case: here, functions are essential which places restrictions on this artist's privilege. And also the interpreter of a play or a musical work of art, being an artist himself, must recognize restrictions which are due to the privilege of deciding about a work being flawless or not of the artist whose work he interprets. 
However if we exclude such cases, even the prevailing law restricts the artist's privilege of deciding about a work being flawless or not only to a very little degree. Only extraordinarily bad printing qualities in the case of graphic sheets, "the use of colours not being non-fading or of bad varnish for contemporary works, particularly wall paintings," besides lacking authenticity, are regularly considered flaws by law courts, which may give the buyer of a new work of art reason to have a warranty claim. ${ }^{5}$ In respect of the durability of photographic copies being below average there are indications of a similar legal practice.

However, speaking of mistakes is common practice with those arts that are based on the division of labour or consist of several phases. As early as in 1755 Winckelmann expressively connects the existence of mistakes in the field of sculpture to the fact that in the course of an extended work which the sculptor cannot produce alone he must employ the hands of his helpers who are not always very skilful with achieving his intentions. Today, the relevant goofs lists in the World Wide Web list more than 60,000 apparent or actual mistakes with films. "Watch Films Differently": the search for mistakes at the cinema - particularly popular are so called connection mistakes - has long since become a receptionaesthetic programme. But here it is possible to speak of mistakes only in respect of film-industrial standards - and typically the lists of mistakes in the World Wide Web include most of all film-industrial mass products. Indeed, as soon as the director of an incriminated film has declared a mistake as being intended, the accusation of a mistake could no longer have been maintained. Only the person finally responsible for a work has the privilege of getting rid of mistakes by denying them, however. Thus, in case of works being produced on the basis of division of labour, being an artist includes the right of the last decision. An artist is a person who is the last to decide about a work being flawless or not. That we also attribute works being produced on the basis of division of labour to a certain individual or a group of individuals is an expression of this fact. With arts for which several phases are typical the situation is similar: here, the artist exerts his right of the last decision either by doing or supervising the entire work process himself, as in the case of printed graphics. Or - as in the case of compositional music and literature - by using a convention of notation he determines what an issue of his work shall be like. Nelson Goodman made this latter aspect the starting point of his distinguishing allographic from autographic arts.?

Even at the interfaces of art and reality the result confirms that it is the artist who has the right of the last decision about a work being flawless 
or not: just imagine that in the course of a project by Orlan the surgeon did not succeed in shaping the artist's face in the way she has set in advance. If thus there was an action by the artist against the surgeon, a law court would have to examine first of all the question of whether the result of the operation is due to the surgeon having neglected or missed the relevant standards of this operation. Thus, it would have to find out if the surgeon can be accused of a professional error. If, however, the artist explicitly accepted the result of the operation - no matter how much different it was from the originally intended and agreed on result - it would not be possible to speak of as an artistic mistake.

One might be of the opinion that it is an arbitrary regulation which decides that it is the respective artist alone who is able to determine the standard a work of art must meet. But it is not. For in ideologically pluralist societies, as the modern age has created in Europe among other places, there are no generally accepted standards which could be made binding for artists. Furthermore, just imagine that artists were really not free to determine the standards to be valid for their works. Then art would not be what we appreciate (and sometimes overestimate) as art. For derivations from socially established norms of art would then always be mistakes, and this would mean - strictly speaking - that there was no artistic further development.

But if it is true that artists have the privilege to determine the standards their works must meet, then artistic work can be characterized as a nomothetic activity, as a legislative act, and if one considers that the Greek culture knew a law of the hands, the nomos cheiron, then artists may be characterized as humans who by way of the thoughts they express in written form or orally, but primarily and first of all with their hands - with their bodies - give laws: an artist is one who makes law with his hands.

Artists are law-makers: by this definition we have gained more than just an explanation for the lack of a category of mistakes with modern aesthetics. For only this way of speaking of the autonomy of arts makes sense at all. Autonomy becomes manifest by the artists' privilege of determining the norms their works must meet and of deciding about their works being flawless or not. Thus, the autonomy of arts is the autonomy of artists: it consists of the capability of giving laws to each of their works and to their entire oeuvre: in most cases they do this indirectly, by creating their works with their bodies, their hands. However, if necessary they also do this by commenting on their works orally or in written form. In a particularly impressive way Beuys's comment on his work Tram 
Station, which at the Hamburger Bahnhof museum in Berlin today forms a really integral part of the work, draws our attention to the nomothetic, indeed domineering act performed by an artist. For, at the Hamburger Bahnhof the observer reads the following sentence by Beuys: "Tram Station is finished in so far as at first it is a result of this action, that is that I said: this thing will be erected in Venice one time and then it will be cut down."

The autonomy of artists shows quite concrete consequences. After all, it is said about some works - probably there are even more arts theoreticians than artists to state this - that with these works the observer becomes a co-producer. Here, things can be put to the test: if the artist, whom we consider the primary originator of the work, is ready to let every recipient co-decide about the work being flawless or not, then this is really a work of which the recipient has become a co-producer. As different recipients may have different opinions about the flaws of a work, however, it is rather probable that in the case of such a work there would be constant debating about it being flawless or not.

The insight that the autonomy of arts must be understood as the autonomy of artists is already predetermined in Kant's analysis of the concept of the genius. However, in the field of philosophic aesthetics this insight has today been mostly replaced by a misleading way of understanding the autonomy of art - a way of understanding which in the course of the past few years has increasingly made the concept of autonomy itself look dubious. The glossary of a book on current art, which has been widely spread by some thousand copies both in the German and the English languages, summarizes the currently predominant opinion very shortly: "For art, autonomy means freedom of any kind of being determined

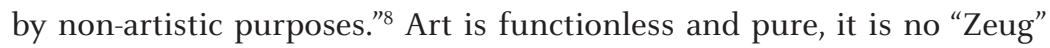
("stuff"), as Heidegger says ${ }^{9}$ - since the Age of Romanticism this conviction has been deeply rooted in the modern way of understanding arts. Already for August Wilhelm Schlegel it was a part of "the nature of the fine arts that they do not want to be useful,"10 in Adorno's opinion the potential of art of being critical of society is due to this fact, and current art theory sticks mostly to this idea of functionless art - even if it increasingly mistrusts its potential of being critical of society.

This way of understanding the autonomy of art is misleading because it restricts art to a purity and functionlessness it does not have. Art is functional in many ways; it may serve a variety of purposes - even those the artist does not approve of. For example, no artist who gives away his 
works and makes them public is able to prevent them from becoming an object of speculation, that they are used for decorative purposes, or for the self-staging of the powerful. If the autonomy of art had really to be understood as functionlessness and purity, it would only be a myth which current art rightly so breaks up ever more offensively. If, in contrast to this, one understands the autonomy of art as a normative, artistic competence, it becomes clear that autonomy and functionality of art are not contradictions.

I would like to emphasize six conclusions from our previous observations:

Firstly: If it is true that by their work artists are unavoidably acting as law-makers, we must consider that laws and norms always have a certain scope. They are not unlimitedly valid but always for a certain territory. No artist is safe from making a mistake while being a road-user or his child's educator. His autonomy does not include his function as a father or roaduser. Thus the artist's autonomous, norm-giving acting must be understood as a kind of acting which is always already referred to a certain area, a territory. Traditionally, the territory of artistic autonomy is called a work, and I follow this language usage. However, one might also consider other names for the area of the artist's nomothetic activity: maybe it is more useful to replace the term work of art by the term project, which much more than the concept of the work would express the fact that today often the scope of artistic autonomy is a hybrid: a constellation of objects, actions, events, and an either specific or coincidental environment. In my opinion it is an advantage of the here suggested concept of artistic autonomy that in this way we are not restricted to the concept of the work. What we are restricted to is only the acceptance of the referential and limited nature of artistic autonomy: its scope is something constituted by acting, which art theory must always newly describe.

Secondly: If one refers the validity of artistic autonomy to a certain field, to a territory which specifically belongs to it, then this spatial way of understanding artistic autonomy already includes the idea of the extensibility of its scope. Indeed, the range of the artistic competence of law-making is in principle limited, but at the same time this limitedness includes that the range of the artistic competence of law-making is something which - just as any field - may be extended. Thus, the here suggested concept of autonomy does precisely not include the idea of a work which is closed in itself. Rather, in this way the tendencies toward delimiting contemporary art may well be explained: as the attempts of artists to extend the scope of their own law-making beyond the so to speak 
original area. It is so to speak the nature of art that the artist is tempted to try out if the field which is subject to the law of his hands could not be extended. An artist's attempt to extend the range of his autonomy, however, may create conflicts, for under certain conditions he will challenge somebody's claims to something. The metaphor of territory makes this potentially combative, warlike nature of the nomos cheiron as immediately reasonable as it is expressed by the Greek term which indeed originally means the law of the jungle. Even disputes among artists about plagiarism and other matters of copyright give evidence to the artist's attempts to claim a certain territory for himself and to defend its borders against real or apparent infringements by other artists. Often, however, the attempt at extending the scope of one's own law-making may be supposed to be due to much more simple reasons: who today makes highly exact regulations on how his picture must be hung or stipulates quite a certain point of view for the observer needs not at all be driven by imperialistic lust for experiment. It is more probable that he only wants to keep his works away from the perception-controlling power of the ubiquitary white cube or that he tries to make visible experiences possible for the observer whom aesthetics has lifted up to be the autonomous subject of aesthetic experience, without this letting him stumble through the exhibition less helplessly than before.

Thirdly: A state who rules over a certain territory needs its claim to be accepted by other states. It suggests itself to transfer this fact to works of art, that is, to those areas where artists claim the competence of lawmaking. Also this claim needs to be accepted by third parties. A work, a project, must be accepted by others as an area which is subject to the law-making of the respective artist. This fact explains the significance of the acceptance an artist's work meets in the world of art and the public. It is this acceptance which secures the scope of autonomy for the respective artist. Thus, when it comes to works not meeting any acceptance not only their aesthetic value is questioned but also always at the same time their status as works of art is at risk. Some art philosophers of the 2oth century (such as George Dickie, ${ }^{11}$ Terence Diffey, ${ }^{12}$ or Stephen Davies ${ }^{13}$ ) have recognized the significance of the fact that something is accepted to be art. However, they have not seen that this is due to the nomothetic nature of artistic activity.

Fourthly: An artist is someone who expresses laws, presents laws, exposes laws which he or she has given him- or herself in respect of a certain area. If this somewhat hits the characterization of the core of that what we call art today, then only now a first aspect of the social 
significance of art becomes obvious. Art shows that autonomy is possible: maybe it does not show this to everybody, but to some people; and it literally makes us aware of the territoriality of autonomy. For the kind of autonomy the possibility of which art gives evidence has always been relative: it has always been referred and limited to a certain area. Who expects art to express truth and celebrates it as a replacement of revelation may consider this a rather humble result. However in my opinion, given the current trend of reducing freedom to an epiphenomenon of neuronal processes, the obvious demonstration of autonomy by art includes an insight which even the lovers of opulent art-philosophic food should not over-hastily reject.

Fifthly: Art shows that autonomy is possible, and it literally makes us aware of the limitedness of autonomy. This is one, but only one aspect of the social meaning of art. Additionally there is a second, very important aspect. It can be recognized if we distinguish two ways of judging art critically: function-related art criticism and conception-related art criticism.

Let us at first have a look at function-related art criticism. Artistic autonomy is far from fighting against the appropriated nature of works of art. Rather, it is the sister of a most varied functionality of art. Thus, works of art can be evaluated as function-related. However, in this context we must distinguish two kinds of the function of art. On the one hand, works of art as works of art have an art-specific function - a function which is typical for works of art: they are able to create an aesthetic experience for which it is typical that it may lead and wants to lead to a kind of understanding - a kind of understanding which often is started again and again because it will not definitely succeed. Furthermore different works of art, however, may have many most different functions and also they may have quite different functions for different observers. These functions need not definitely be art-specific - they are functions which in principle may also be attributed to other things. Such secondary functions of art may definitely be art-immanent functions: works of art may contribute to the further development of or to reflection on those topics and problems, ways of designing and methods which so to speak are the interior aspect of the social institution of art. But works of art may also have political or ideological functions, they may serve for commemorating individuals or events or they may decorate rooms, they may express emotions and experiences or they themselves may create certain emotions or moods with the observer. ${ }^{14}$ As long as there are works of art which serve such or other purposes, there will be function-related art criticism that judges works of art according to their suitability for certain purposes (and which often, 
as it misunderstands the autonomy of art as the latter being pure, makes much effort to hide that it does so).

Thus, the critic's subjective judgement on the question of which function is how important will always be a part of any function-related artcritical judgement. Every general judgement on the value of a work of art will thus always also reflect the order of priority of the functions of art which seems to be appropriate for the judging individual against the background of his respective understanding of the world and of himself. Somebody will have the impression that a work is successful if in his opinion it fulfils a function which for him is of particular importance. Such a kind of function-oriented art criticism is in principle not fundamentally different from judging, for example, electric coffee machines. For example, not every electric coffee machine is able to keep the coffee warm or, if necessary, to automatically decalcify itself. And not all of them make it possible for us to watch the process of boiling. If we prefer a coffee machine to have a certain function to any other one, this depends among other things on how important we consider just this particular function to be. In respect of function-related art criticism the situation is similar. Thus, that what one critic considers a failure may be an example in the eyes of another. In so far, function-related art criticism cannot rid itself of the subjectivity of the judging one. It can always only result in a judgement on the question if, from the point of view of the way the judging one understands the world and him- or herself, the respective work of art is a failure or a success. Thus, art has always been a reason for us to discourse about preferences, our ideas and desires, our judgements on value and our priority-making. Already due to this it has a social significance and function. For as soon as it gives us a reason for function-related art criticism, art forces us to make our preferences, our ideas and desires, our judgements on value and priority-making obvious. As the debate on the question if a certain work of art is good or bad has always indirectly been referred to the question of which potential functions of art shall be preferred to others, it indirectly has always also concerned questions such as that of how we want to live and of how in our opinion humans should live together and how the society in which we or others live should be organized. And as it concerns such questions, to which every society must again and again find new answers, in my opinion the debate on the function-related quality of works of art is indispensible. This is also true because works of art are a particularly suitable reason for this debate. For they offer us a reason in the context of which we are usually not under immediate pressure to act (in so far 
they offer us a comparably harmless reason). And in most cases they are a kind of reason for this debate which prevents us from taking refuge to simple everyday insights (for in most cases they are a comparatively complex reason which is not transparent at first sight).

Sixthly: However, on the other hand artistic autonomy also includes the possibility of an artist making his concept public in a quite expressive way. If an artist does so, he makes a kind of conception-related art criticism possible which always assumes and respects the artist's lawmaking. For conception-related art criticism is orientated at norms which either can be clearly read from the work itself or which have been made explicit outside the work by the artist himself. This kind of art criticism is made possible by the artist, to a certain extent sharing his privilege of the last decision about mistakes with a sufficiently informed observer. By making his criterion public, the artist takes the risk that also an observer will discover inconsistencies with his work: violations of the artist's individual norm of designing. The fact that ever less artists shrink away from this risk is shown by the constantly increasing number of artistic manifests and self-comments. It gives evidence to how important it is for many artists to make their work accessible to a kind of art criticism for which they themselves may define the criterion.

However, even a critic who is intimately familiar with an artist's lawmaking will not be able to invalidate the artist's mistake-privilege. For it is a part of artistic autonomy that the Lord of the Flaws may change his criterion at any time, and that also he has the last word on how this criterion must be interpreted. Thus, even the informed observer, who has intensively studied the artistic concept of a certain artist, cannot claim to state a mistake. Instead, he can only state that a work is a failure. For even he must recognize the artist as the Lord of the Flaws: that is the price the recipient of modern art must pay for the artist's autonomy. To believe that it could be bought for less would be - a mistake.

\section{Notes}

1. Aristotle, Poetics (ch. 25, 146ob), in Aristotle's theory of poetry and fine art: With a critical text and translation of the "Poetics," 3rd ed., trans. Samuel Henry Butcher (London: Macmillan, 1902).

2.Cf. Pietro C. Marani, Leonardo: Das Werk des Malers (Munich: Schirmer Mosel, 2005), $48 \mathrm{ff}$.

3. Götz Adriani, Cézanne: Gemälde (Cologne: DuMont, 1993), 154.

4. Ibid. 
The Lord of the Flaws: The Autonomy of the Artist and the Function of Art

5. Haimo Schack, Kunst und Recht: Bildende Kunst, Architektur, Design und Fotografie im deutschen und internationalen Recht (Cologne: Heymann, 2004), 155.

6.Cf. http://www.moviemistakes.com; http://wallywood.co.uk; http://zidz.com /goofs.php; http://imdb.com/Sections/Goofs; hhtp://www.dieseher.de.

7. Cf. Nelson Goodman, Languages of Art: An Approach to a Theory of Symbols. 2nd ed. (Indianapolis, Ind. and Cambridge, Mass.: Hackett, 1976), 127-224.

8. Art Now, eds. Burkhard Riemschneider and Uta Grosenick (Cologne: Taschen, 2001), 185 .

9. Martin Heidegger, Der Ursprung des Kunstwerkes (Stuttgart: Reclam, 1986), $21 \mathrm{ff}$.

10. August Wilhelm Schlegel, Die Kunstlehre (Kritische Schriften und Briefe, vol. II), ed. Edgar Lohner (Stuttgart: Kohlhammer, 1963), 13.

11. Cf. George Dickie, “Defining Art,” American Philosophical Quarterly 6 (1969): 253-256; George Dickie, Art and the Aesthetic: An Institutional Analysis (Ithaca, N.Y. and London: Cornell University Press, 1974); George Dickie, The Art Circle: A Theory of Art (New York: Haven, 1984); George Dickie, Art and Value (Malden, Mass.: Blackwell, 2001).

12. Cf. Terence Diffey, "The Republic of Art," The British Journal of Aesthetics 9 (1969): 145-156; Terence Diffey, “On Defining Art," The British Journal of Aesthetics $19(1979): 15^{-23}$.

13. Cf. Stephen Davies, "A Defense of the Institutional Theory of Art," The Southern Journal of Philosophy 26 (1988): 307-324; Stephen Davies, Definitions of Art (Ithaca, N.Y. and London: Cornell University Press, 1991).

14. Cf. Reinold Schmücker, "Funktionen der Kunst", in Wozu Kunst? Die Frage nach ihrer Funktion, eds. Bernd Kleimann and Reinold Schmücker (Darmstadt: WBG, 2001), 13-33. 